\title{
Persepsi Guru Dampak Pandemi Covid-19 terhadap Pelaksanaan Pembelajaran Daring di PAUD
}

\author{
Arifah Prima Satrianingrum ${ }^{1 凶}$, Iis Prasetyo ${ }^{2}$ \\ Pendidikan Anak Usia Dini, Universitas Negeri Yogyakarta \\ DOI: $10.31004 /$ obsesi.v5i1.574
}

\begin{abstract}
Abstrak
Tujuan dari penelitian ini adalah untuk memaparkan informasi terkait persepsi guru mengenai tantangan pelaksanaan pembelajaran daring di rumah akibat dampak dari pandemi COVID-19. Informasi persepsi guru mengenai tantangan pelaksanaan pembelajaran daring menggunakan studi kasus dengan pendekatan kualitatif. Informan terdiri dari 7 orang guru PAUD di kota Padang. Hasil dari penelitian ini mengungkapkan bahwa kurang memadainya sarana dan prasarana, kurang maksimalnya penyampaian materi, beban pembelian kuota internet, koneksi internet yang kadang menjadi lamban, gaya belajar yang cenderung visual, serta kurang leluasanya guru dalam mengontrol kegiatan siswa.
\end{abstract}

Kata Kunci: pembelajaran daring; paud; covid-19; persepsi guru.

\begin{abstract}
The purpose of this study is to describe information related to teacher perceptions the challenges of implementing online learning at home due to the impact of the COVID-19 pandemic. Information on teacher perceptions about the challenges of implementing online learning using case studies with a qualitative approach. The informants consisted of 7 Early Childhood Education teachers in the city of Padang. The results of this study reveal that inadequate facilities and infrastructure, less than the maximum delivery of material, the burden of internet quota purchases, internet connections that sometimes become slow, learning styles that tend to be visual, and the lack of flexibility of teachers in controlling student activities.
\end{abstract}

Keywords: online learning; early childhood education; covid-19; teacher's perceptions.

Copyright (c) 2020 Arifah Prima Satrianingrum, Iis Prasetyo

$\triangle$ Corresponding author :

Email Address : aprimasatrianingrum@yahoo.com (Komp. Filano Jaya I Padang)

Received 1 June 2020, Accepted 17 Juli 2020, Published 1 August 2020

\section{PENDAHULUAN}

Pada akhir tahun 2019 munculnya infeksi virus yang menyebar secara cepat, virus tersebut dinamakan COVID-19. Virus ini pertama kali ditemukan di Wuhan, China. COVID19 menyebar secara massif di negara-negara lainnya. World Health Organization (WHO) mengumumkan pada tanggal 11 Maret 2020 bahwa COVID-19 dinyatakan sebagai pandemi. Sampai saat ini ada 215 negara yang terjangkit virus corona, dengan laporan terinfeksi sebanyak 12.768.307 kasus yang terjangkit (WHO, 2020)). Indonesia adalah salah satu negara yang terjangkit COVID-19. Virus ini sudah tersebar di Indonesia pada Maret lalu hingga hari ini. Sebanyak 72.347kasus positif COVID-19 di Indonesia(Gugus Tugas Percepatan COVID-19 
Indonesia, 2020). Pandemi COVID-19 membawa pengaruh kepada semua lintas kehidupan, khusunya pendidikan. Akibat dari pandemic COVID-19, pelaksanaan sekolah dari taman kanak-kanak hingga universitas di tutup. UNESCO mengatakan bahwa 300 juta murid terganggu kegiatan sekolahnya dan penutupan sekolah sementara akibat dari kesehatan dan krisis (Handoyo, 2020)). COVID-19 membuat suatu uji coba terhadap pelaksanaan pendidikan secara daring yang dilakukan secara massal (Sun, Tang, \& Zuo, 2020).

Ribuan sekolah di negara lain, termasuk Indonesia, menutup sekolah sebagai upaya untuk menghentikan penyebaran COVID-19 (CNN Indonesia, 2020). Tanggapan UNESCO sebagai lembaga yang bergerak di bidang pendidikan, sangat menyetujui pelaksanaan pembelajaran dengan menggunakan wadah daring upaya pembelajaran jarak jauh, sehingga pembelajaran dapat dijangkau oleh murid dimana pun berada. Perubahan dari pelaksanaan pembelajaran dalam kelas hingga pelaksanaan pembelajaran dalam jaringan ini, yang berperan sebagai aktor terpenting ialah guru dan pendidik, karena mereka adalah pengendali dalam proses pembelajaran (Bao, 2020; Braisilaia\& Kvavadze, 2020). Pengaplikasian pembelajaran daring ini adalah bukti dari revolusi industry 4.0, dimana pengaksesan teknologi tidak terbatas, sehingga memungkinkan pelaksanaan pembelajaran daring atau jarak jauh (Verawardina\& Jama, 2018).

Untuk memutuskan mata rantai penyebaran COVID-19 diperlukan kerjasamanya semua pihak dalam mengatasinya (Pikiran-Rakyat.com, 2020), upaya yang dilakukan pemerintah adalah tidak berkerumun dalam keramaian, tidak pergi ke pasar, tempat perolahragaan, tempat budaya dan lain sebagainya. Serta masyarakat yang bekerja di kantor, diusahakan untuk melakukan pekerjaan di rumah saja (Work From Home). Begitu pun pada bidang pendidikan, pembelajaran dilakukan dirumah saja (Learning From Home). Learning From Home merupakan pengalaman pertama yang dilakukan secara massal di Indonesia. Banyak pelajar dan guru belum terbiasa dengan Learning From Home yang dilakukan secara daring (KBRI Hanoi, 2020).

Surat edaran mengenai kebijakan sekolah saat pandemi yang diluncurkan oleh Menteri Pendidikan dan Budaya pun memberikan ketentuan, yakni proses pembelajaran dilaksanakan dari rumah untuk memberikan pembelajaran yang bermakna melalui pembelajaran daring atau jarak jauh (Mendikbud, 2020). Ciri dari pembelajaran online atau daring adalah integrasi teknologi dan inovasi yang ada didalamnya(Banggur \& Situmorang, 2018). Hal ini dilakukan dari jenjang pendidikan anak usia dini hingga perguruan tinggi. Pada beberapa sekolah di Indonesia sudah biasa menerapkan metode pembelajaran daring, namun disisi lain, ada juga sekolah yang baru pertama kali melakukan pembelajaran secara daring. Pendidik yang biasanya mengajar secara konvensional di kelas, tiba-tiba harus mengajar dalam sebuah media. Ditambah dengan adanya sejumlah pendidik yang belum melek teknologi. Dalam pembelajaran sistem daring, ada beberapa kendala yang dirasa kurang efektif, seperti pemberian materi pembelajaran oleh guru, melek teknologi dari guru maupun orang tua yang akan membimbing anak, serta keadaan ekonomi anak (Muhdi \& Nurkolis, 2021). Hal tersebut merupakan salah satu tantangan para pendidik dan guru di masa pandemi ini. Beberapa penelitian mengungkapkan bahwa sistem pembelajaran daring memberikan sisi positif, namun ada juga hal yang kurang menguntungkan dibalik hal tersebut(Taufik, 2019).

Dengan kondisi tersebut diatas, proses pembelajaran pada jenjang pendidikan anak usia dini haruslah tetap berlangsung, bahkan perhatian kepada mereka diberikan lebih dari kondisi normal. Apalagi pada anak yang orang tuanya menjadi garda terdepan penangan covid-19. Anak memerlukan pendidikan untuk mengoptimalkan seluruh aspek perkembangannya (Purwanti, 2013) demi masa depan dalam menempuh jenjang berikutnya (Kementerian Pendidikan dan Kebudayaan, 2003)

Berdasarkan uraian tersebut, penelitian ini akan mendeskripsikan informasi mengenai tantangan yang dirasakan guru akibat dampak pandemic COVID-19 di tingkat pendidikan PAUD di Kota Padang. 


\section{METODOLOGI}

Metode dalam penelitian ini menggunakan studi kasus dengan pendekatan penelitian kualitatif. Studi kasus merupakan penelitian yang memaparkan suatu fenomena terjadi dengan menjelaskan suatu kasus yang terjadi pada kelompok, sehingga dapat memberika informasi yang penting untuk menjadi perhatian(Hodgetts, \& Stolte, 2012). Sehingga diperoleh informasi mengenai tantangan dari dampak pandemic COVID-19 terhadap pelaksanaan pembelajaran daring. Respoden dalam penelitian ini berjumlah sebanyak 8 orang guru. Wawancara yang dilakukan secara terstuktur dan diperluas pertanyaannya melalui referensi terkait. Responden yang memberikan jawaban berasal dari guru pendidikan anak usia dini yang berada di Kota Padang. Dilihat dari status kondisi sosial ekonomi, Kota Padang mencapai garis kemiskinan di angka 92.541 (BPS, 2019).

Tabel 1. Profil Responden

\begin{tabular}{ccc}
\hline Isinial & Jenis Kelamin & Pendidikan \\
\hline G1 & Perempuan & S1 \\
\hline G2 & Perempuan & S1 \\
\hline G3 & Perempuan & S1 \\
\hline G5 & Perempuan & S1 \\
\hline G6 & Perempuan & S1 \\
\hline G7 & Perempuan & S1 \\
\hline
\end{tabular}

Data primer dalam penelitian ini adalah wawancara terstruktur dengan guru dengan data sekunder dari kumpulan artikel jurnal dan referensi yang tersedia dan dianalisis. Teknik pengumpulan data adalah cara yang dilakukan peneliti untuk mengumpulkan data yang objektif(Margono, 2010). Dalam penelitian ini responden diwawancarai hingga diperoleh data yang dicari. Untuk mendapatkan informasi mengenai perspektif guru dampak COVID-19 terhadap proses pembelajaran daring disusun beberapa pertanyaan mengacu dari instrument salah satu penelitian(Purwanto, Pramono, Asbari, Santoso, Wijayanti, Hyun, 2020): 1) Jelaskan dampak pandemic COVID-19 yang dialami murid pada proses pembelajaran daring!; 2) Jelaskan dampak pandemic COVID-19 yang dialami guru dalam proses pembelajaran daring!; 3)Jelaskan tantangan proses pembelajaran daring selama pandemic COVID-19!
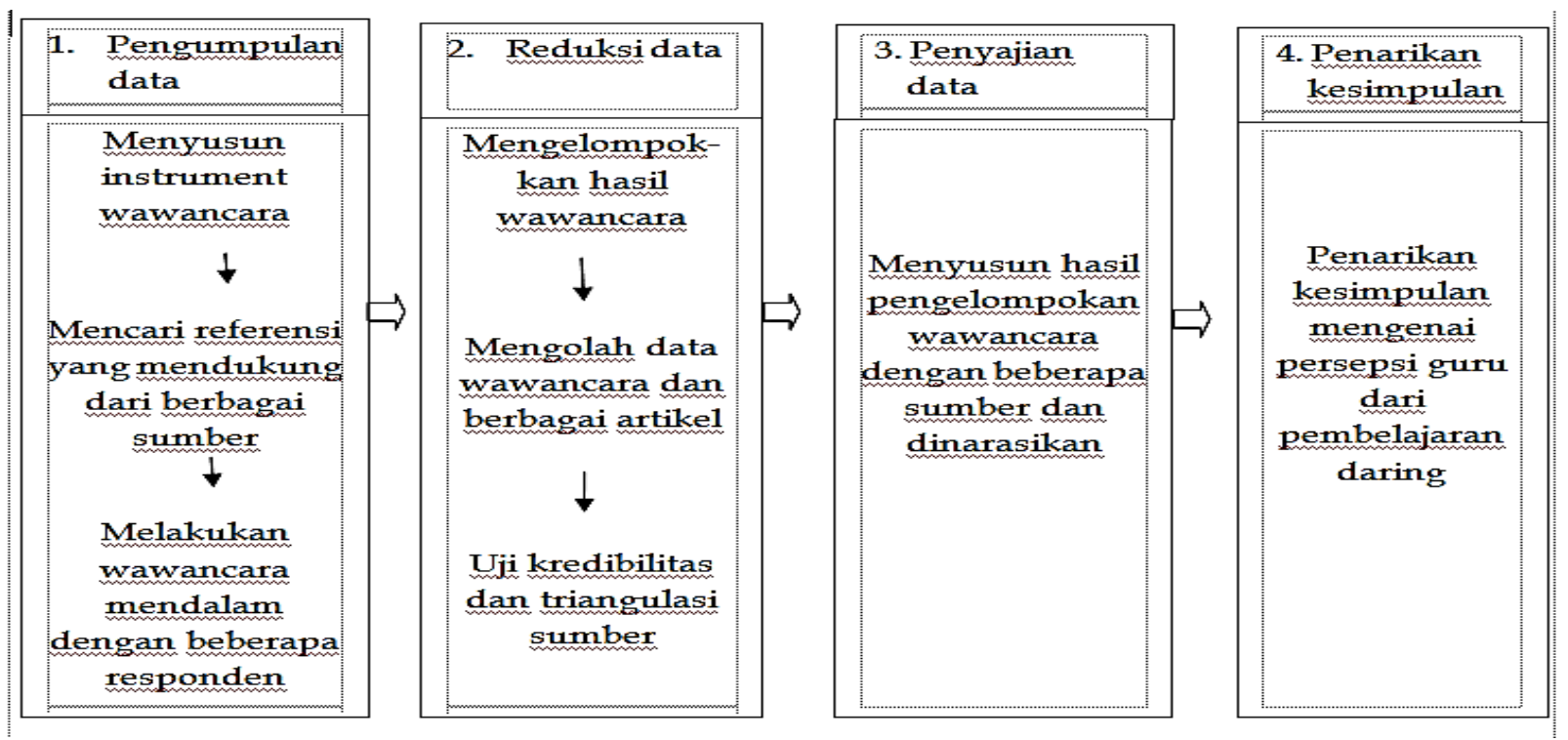

Gambar 1. Langkah-langkah Penelitian 


\section{HASIL DAN PEMBAHASAN}

Penelitian ini memaparkan informasi persespsi guru mengenai pelaksanaan pembelajaran daring di PAUD di Kota Padang. Tujuh responden memberikan pendapat mereka dan dijelaskan dengan pembahasan berikut.

\section{Dampak Pandemik terhadap Murid}

Responden G1 menyatakan bahwa ada sebagian dari orang tua murid tidak menggunakan perangkat-perangkat yang memadai. Dalam pelaksanaan pembelajaran secara daring yang dilakukan di rumah, salah satuketerbatasan dalam pelaksanaan ini ialah sarana dan prasarana yang mendukung, seperti laptop, komputer, handphone, kouta internet dan lain sebagainya. Sarana prasarana menjadi begitu penting dalam mengakomodasi pelaksanaan pembelajaran bagi murid.

Pelaksanaan pembelajaran daring dirasa belum optimal dalam penyampaian materi pembelajaran kepada murid, karena biasa belajar di kelas secara face-to-face, sekarang penyampaian materi melalui sebuah wadah. Sehingga guru merasa bahwa pembelajaran menjadi tidak bermakna bagi murid. Salah satu faktornya ialah pembelajaran tidak dilakukan dengan tatap muka secara langsung, maka proses pembelajaran lebih difokuskan dalam bentuk penugasan kepada murid. Ditambah dengan kurangnya minat murid, karena melakukan pembelajaran melalui sebuah grup di aplikasi yang dominan berisi teks. Hal tersebut hanya menstimulasi daya visual anak."Apalagi setelah melakukan pembelajaran secara daring, anak-anak lebih banyak bermain handphone setelah pembelajaran" ungkap orang tua yang menceritakan kepada responden G5.

Sebuah penelitian terdahulu memaparkan bahwa gaya belajar murid dalam pembelajaran secara daring cenderung lebih visual dan baca tulis yang kuat(Drago,\& Wagner, 2004). Banyaknya platform yang mendukung secara gratis, seperti Google Classroom, Whatsapp, Quipper dan lain sebagainya(Abidah, Hidayaatullaah, Simamora, Fehabutar,\& Mutakinati, 2020)yang dapat mengirimkan pesan teks, gambar, video dan file lain(Kusuma, 2020)namun penggunaan platform tersebut belum efektif, karena keterbatasan sarana prasarana di sebagian murid kurang memadai.

Pelaksanaan pembelajaran secara daring terkesan tidak rata dan cenderung teachercentered. Ditambah lagi, jika melakukan sebuah diskusi, ada yang menjadi silence reader dan respon dari murid pun sedikit lebih pendek (Moorhouse, 2020). Penelitian ini didukung dalam temuannya 1 dari 58 siswa sangat paham mengenai pembelajaran secara daring, 23 dari 58 siswa mengerti, dan selebihnya mereka menjawab kadang mengerti (Anhusadar, 2020). Proses interaksi antara pengontrolan dan lingkungan kelas, sangat berpengaruh kepada murid, seperti misalnya semangat siswa yang terjadi saat di lingkungan ruangan kelas (Hershkovitz, Elhija, \&Zedan, 2019), namun akan berbeda jika melakukan pembelajaraan saat dirumah. Sehingga tidak menimbulkan motivasi yang tinggi. Selain itu, sarana prasarana yang menjadi fasilitas utama dalam lancarnya pelaksanaan pembelajaran daring ini. Responden G1 menyatakan bahwa terkadang dalam melaksanakan proses pembelajaran daring, jaringan tiba-tiba menjadi lamban,dan responden G3 menambahkan, bahwa kuota internet merupakan momok utama yang berperan penting dalam pelaksanaan pembelajaran, habis ditengah jalan.Kendala yang ditemukan yakni penggunaan jaringan internet yang membutuhkan biaya dan kemampuan orang tua dalam memberikan fasilitas pendidikan secara daring, kurangnya pembelajaran bersikap yang baik, kurangnya disiplin diri, serta lingkungan ketika terisolasi dirumah(Bao, 2020; Jones, \& Sharma, 2019; Obiakor, \& Adeniran, 2020; Purwanto, Pramono, Asbari, Santoso, Wijayanti,\&Hyun, 2020).

\section{Dampak Pandemik terhadap Guru}

Pandemic ini memberikan dampak bagi guru dalam proses pembelajaran secara daring, karena guru tidak leluasa memantau perkembangan anak secara keseluruhan, responden G1, G2, G5, dan G7 sependapat bahwa dalam mengontrol anak dari jarak jauh 
adalah sebuah keterbatasan, ditambah dengan adanya anak yang jarang dibimbing oleh orang tua dan juga kurangnya pemahaman orang tua terhadap perkembangan anak, sehingga proses pembelajaran sebagian besar tidak terlaksana secara maksimal. Ditambahkan oleh responden G2 yang menyampaikan bahwa kurang optimalnya penyampaian materi pembelajaran yang disampaikan kepada murid, sehingga pembelajaran dirasa kurang bermakna bagi murid. Dalam penyampaian materi, guru juga terbatas metode ajar yang akan disampaikan, mengingat jumlah kuota yang dimiliki oleh orang tua murid dan guru, sehingga pembelajaran dilakukan dalam grup di aplikasi. Namun, walau pun begitu, tidak ada perubahan dalam banyaknya porsi kerja guru dalam menyiapkan proses pembelajaran yang terbaik bagi murid, ungkap reponden G3 dan G4.

Dalam temuan lain dari kasus pelaksanaan pembelajaran online adalah guru merasa bingung dan merasa repon yang diharapkan tidak pasti, sehingga apakah guru melakukan pembatasan peran atau harus melakukan perluasan peran secara online(Forkosh-Baruch, \& Hershkovitz, 2014). Dalam pelaksanaan pembelajaran secara daring, banyak penelitian yang mengungkapkan bahwa pembelajaran ini lebih efiesien dalam biaya dan tenaga. Karena menurut responden G6 bahwa tidak semua murid berasal dari keluarga yang berada, apalagi pandemik ini membuat keluarganya susah mencari nafkah. Perlu adanya kreativitas dari guru dalam merencanakan instruksi daring secara efektif. Gaya pengajaran dalam pembelajaran daring pun perlu diperluas, karena cukup berbeda dengan pembelajaran yang berada dalam ruangan (Purwanto, Pramono, Asbari, Santoso, Wijayanti, \& Hyun, 2020). Dalam pembelajaran dalam ruangan, bahasa tubuh guru, ekspresi wajah dan suara adalah hal yang utama. Namun, ketika beralih ke platform, mereka menyediakan terdapat berbagai menu yang dapat dibagikan, seperti teks, video, gambar, suara dan lainnya. Sehingga dalam pembelajaran daring guru harus memilih strategi yang tepat dalam menyampaikan materi (Bao, 2020).

\section{Tantangan Proses Pembelajaran Daring}

Tantangan mewarnai proses pembelajaran daring ini. Karena jaringan yang lamban, sehingga informasi ataupun materi yang disampaikan memerlukan waktu yang cukup lama untuk di terima oleh orang tua, atau pun sebaliknya. Hal ini juga faktor dari jarak dan keterbatasan jaringan yang berada di lingkungan tempat tinggal murid.Repon dari G6 menyatakan bahwa dalam pembelajaran, materi yang disampaikan terkadang tidak sejalan dengan apa yang ditargetkan guru. G7 menambahkan bahwa dalam pengumpulan tugas pun kewalahan memberikan jangka waktu karena berbagai alasan yang diberikan oleh murid. Dilihat dari salah satu faktor yang mempengaruhi, yakni kuota internet menjadi kendala utama dalam proses pembelajaran daring, karena kuota internet mengakomodasi lancarnya proses pembelajaran daring.

Tantangan bagi guru dalam proses pembelajaran daring ialah penugasan yang diberikan kepada murid tidak sepenuhnya murid yang melakukan, adanya campur tangan orang tua dalam proses penugasan. Namun, ada juga orang tua yang tidak dapat membersamai dirumah, sehingga tidak ada yang dapat membantu dalam mengakomodasi sarana pembelajaran murid. "Murid kadang dalam mengerjakan tugas, tidak sepenuhnya ia yang melakukan ataupun ada juga orang tua tidak ada dirumah, sehingga tidak ada yang dapat membantu dalam mengakomodasi sarana pembelajaran murid", ungkap G4. Responden G7 lebih mengedepankan keterbatasan media saat pelaksanaan pembelajaran daring dilaksanakan, ia juga menambahkan bahwa masih ada murid dan orang tua yang belum melek teknologi.

Sebuah penelitian menyatakan bahwa aktivitas dalam pengajaran tidak mudah dalam memfasilitasi (Moorhouse, 2020). Namun, gabungan antara keselarasa dan mode ketidakselarasan dari instruksi dilihat menjadi sebuah cara dalam mendukung pembelajaran dalam teknologi ketika face-to-face tidak menjadi pilihan. Pembelajaran daring memberikan manfaat yang luas, yakni dapat menjangkau ke seluruh wilayah, namun dalam temuan lainnya menyatakan bahwa ada beberapa kendala yang dihadapi di beberapa wilayah 
Indonesia, yang mana penyebaran dan keterjangkauan layanan internet yang menjadi lamban sewaktu-waktu. Juga jika penggunaan platform banyak dalam satu grup, maka akan menyebabkan overload (Bao, 2020; Pramudibyanto, Khasanah, \& Widuroyekti, 2020). Serta tantangan yang dirasakan oleh dalam pelaksanaan pembelajaran daring ialah belum adanya kurikulum yang tepat dalam situasi seperti saat ini, ketersediaan sarana dan prasarana yang belum memadai, seperti teknologi dan jaringan internet serta kesiapan sumber daya manusia itu sendiri, salah satunya pendidik. Sehingga dengan kondisi yang sedang dihadapi mengahruskan tenaga pendidik dan guru untuk lebih adaptif serta inovatif (Ahmed, Shehata, \& Hasanien, 2020; Arifa, 2020). Apalagi ditambah dengan ditribusi guru yang tidak merata (Mahbub et al., 2020). Guru terpusat pada perkotaan, sedangkan pada pedesaan lebih banyak kendala yang dihadapi.

Dengan pelaksanaan pembelajaran daring ini tetaplah menjadikan guru dan murid tetap dekat walaupun melalui komunikasi instant messaging platform (IMP). Hal terpenting tantangan tersebut tetap di evaluasi agar mendapatkan pembelajaran yang maksimal dan menciptakan keterampilan belajar yang mandiri dalam pandemik ini (Herliandry, Nurhasanah., Suban,\& Kuswanto, 2020).

\section{SIMPULAN}

Berbagai ragam dampak dan tantangan yang dihadapi dalam melaksanakan proses pembelajaran daring di rumah. Persepsi guru mengenai dampak yang dirasa pada murid ialah ketersediaan sarana dan prasarana yang kurang memadai, perbedaan atmosfir saat belajar dikelas dengan belajar dirumah, yang berpengaruh pada motivasi murid. Serta kecenderungan gaya belajar daring ialah visual dan tulisan. Guru dan murid merasakan beban pada kuota internet, terlebih lagi jika berada di kawasan yang terganggu sinyal, pemantauan perkembangan anak terbatas, guru merasa tidak leluasa seperti di kelas.Untuk ke depannya perlu di evaluasi mengenai pelaksanaan pembelajaran daring. Sehingga memberikan hasil yang maksimal.

\section{UCAPAN TERIMA KASIH}

Terima kasih kepada seluruh pihak yang terlibat dalam proses pembuatan artikel ini. Serta kepada tim redaksi jurnal obsesi yang telah memberikan masukan yang konstruktif untuk peningkatan kualitas artikel ini.

\section{DAFTAR PUSTAKA}

Abidah, A., Hidaayatullaah, H. N., Simamora, R. M., Fehabutar, D., \& Mutakinati, L. (2020). The Impact of Covid-19 to Indonesian Education and Its Relation to the Philosophy of "Merdeka Belajar." Studies in Philosophy of Science and Education, 1(1), 38-49. https:// doi.org/10.46627/sipose.v1i1.9

Ahmed, S., Shehata, M. H., \& Hasanien, M. (2020). Emerging faculty needs for enhancing student engagement on virtual platform. MedEdPublish. https:// doi.org/http://doi.org/10.15694/mep.2020.000075.1

Anhusadar, L. O. (2020). Persepsi mahasiswa PIAUD terhadap kuliah online di masa pandemik COVID-19. Kindergarten: Journal of Islamic Early Childhood Education, 3(1), 4458. https:/ / doi.org/https://dx.doi.org/10.2414/kjiece.v3i1.9609

Arifa, F. N. (2020). Tantangan pelaksanaan kebijakan belajar dari rumah dalam masa darurat COVID-19. Bidang Kesejahteraan Sosial Kajian Singkat Terhadap Isu Aktual Dan Strategi, 12(1), 1-7.

Banggur, M. D., Situmorang, R., \& R. (2018). Pengembangan pembelajaran berbasis blended learning pada mata pelajaran etomologi multimedia. JTP Jurnal Teknologi Pendidikan, 20(2), 152-165. https://doi.org/http:/ / doi.org/10.21009/JTP2002.5

Bao, W. (2020). COVID-19 and online teaching in higher education: A case study of Peking 
DOI: 10.31004/obsesi.v5i1.574

University. Pedagogical Research, 5(4), 113-115.
https://doi.org/https://doi.org/10/1002/he2.191

BPS. (2019). Sensus Data: Garis kemiskinan menurut KabupatenKota di Provinsi Sumatera Barat, 2000, 2002-2019. Http:/ / / Padangkota.Bps.Go.Id.

Braisilaia, G., \& Kvavadze, D. (2020). Transition to online education in schools during a pandemic in Georgia. Pedagogical Research, 5(4), 1-9. https://doi.org/https://doi.org/10.29333/pr/7937

CNN Indonesia. (2020). Studi Pertanyakan Efektivitas Penutupan Sekolah Cegah Corona. https://www.cnnindonesia.com/gaya-hidup/20200408103445-284-491518/studipertanyakan-efektivitas-penutupan-sekolah-cegah-corona

Drago, W. A., \& Wagner, R. G. (2004). Vark preffered learning styles and online education. Management Research News, 27, 1-13. https://doi.org/https://doi.org/10.1108/0140917041078211

Forkosh-Baruch, A., \& Hershkovitz, A. (2014). Teacher-student relationship in the facebook-area (In P: Isai). IGI Global. https://doi.org/10.1504/TJCEELL. 2013.051765

Gugus Tugas Percepatan COVID-19 Indonesia. (2020). Data COVID-19 dan Indonesia. Handoyo. (2020). Wabah virus corona ancam 300 juta siswa. Kontan.Co.Id.

Herliandry, L. D., Nurhasanah., Suban, M. E., \& Kuswanto, H. (2020). Pembelajaran pada masa pandemi COVID-19. Jurnal Teknologi Pendidikan, 22(1), 65-70. https://doi.org/http://doi.org/10.21009/jtp.v22i1.15286

Hershkovitz, A., Elhija, M. A., Zedan, D. (2019). WhatsApp is the message: Out of class communication, student-teacher relationship, and classroom enviroment. Journal of Information Technology Education: Research, 18.

Hodgetts, D. J., \& Stolte, O. M. (2012). Case-based research in community and social psychology: Introduction to the special issue. Journal of Community $\mathcal{E}$ Applied Social Psychology, 22, 379-389. https:// doi.org/10.1002/casp.2124

Jones, K., \& Sharma, R. (2019). Reimagining a future for online learning in the post-COVID era. SSRN Electronic Journal. https:// doi.org/10.2139/ssrn.3578310

KBRI Hanoi. (2020). Langkah dan Upaya Pemerintah Indonesia Dalam Menangani dan Menghadapi COVID-19. Kemlu Website. https://kemlu.go.id/hanoi/id/news/5105/langkah-danupaya-pemerintah-indonesia-dalam-menangani-dan-menghadapi-covid-19

Kementerian Pendidikan dan Kebudayaan. (2003). Undang-Undang No. 20 Tahun 2003 tentang Sistem Pendidikan Nasional (Sisdiknas) dan Penjelasannya. Media Wacana Press.

Kusuma, J. W., \& H. (2020). Platform whatsapp grup dan webinar zoom dalam pembelajaran jarak jauh pada masa pandemik COVID-19. Jurnal Ilmiah Pendidikan Matematika, 5(1), 97. https:// doi.org/10.26877/jipmat.v5i1.5942

Mahbub, M., Purnamawati, D., Maslamah, Sopakua, S., \& Fauziddin, M. (2020). Educational data mining with clustering technique on the distribution of civil servant teachers in Indonesia. Journal of Advanced Research in Dynamical and Control Systems, 12(6), 20972103. https:// doi.org/10.5373/JARDCS/V12I6/S20201171

Margono, S. (2010). Metodologi penelitian pendidikan. Rineka Cipta.

Mendikbud. (2020). Surat edaran Mendikbud: Pembelajaran secara daring dan bekerja dari rumah dalam rangka pencegahan penyebaran corona virus disease (COVID-19).

Moorhouse, B. L. (2020). Adaptations to face-to-face initial teacher education course "forced" online due to the COVID-19 pandemic. Journal Education for Teaching: International Research and Pedagogy. https://doi.org/https://doi.org/10/1080/02607476.2020.1755205

Muhdi, \& Nurkolis. (2021). Keefektivan Kebijakan E-Learning berbasis Sosial Media pada PAUD di Masa Pandemi Covid-19. Jurnal Obsesi : Jurnal Pendidikan Anak Usia Dini, 5(1), 212-228. https://doi.org/10.31004/obsesi.v5i1.535

Obiakor, T., \& Adeniran, A. (2020). COVID-19: Impending situation threatens to deepen Nigeria's education crisis. Center for the Study of the Economi of Africa, 1-7. 
Pikiran-Rakyat.com. (2020). Tanggungjawab Bersama, Memutus Mata Rantai Penyebaran Covid19. Pikiran-Rakyat.Com. https://www.pikiran-rakyat.com/bandung-raya/pr01390686/tanggungjawab-bersama-memutus-mata-rantai-penyebaran-covid-19

Pramudibyanto, H., Khasanah, D. R., \& Widuroyekti, B. (2020). Pendidikan dalam masa pandemik COVID-19. Jurnal Sintesa, 10(1), 41-48.

Purwanti, F. (2013). Peningkatan Kemampuan Berhitung Melalui Permainan Balok Angka Pada Anak Kelompok B Di TK Universal Ananda Kecamatan Patebon Kendal. Jurnal Pendidikan, 41-42.

Purwanto, A., Pramono, R., Asbari, M., Santoso., P. B., Wijayanti, L. M., Hyun, C. C., et al. (2020). Studi eksploratif dampak pandemi COVID-19 terhadap proses pembelajaran online di sekolah dasar. Journal of Education, Psychology, and Counseling, 2, 1-9.

Sun, L., Tang, Y., \& Zuo, W. (2020). Corona virus pushes education online. Nature Material, 19, 687. https://doi.org/https://doi.org/10.1038/s41563-020-0678-8

Taufik, A. (2019). Perspektif tentang perkembangan sistem pembelajaran jarak jauh di Kabupaten Kutai Kartanegara Kalimantan Timur. Jurnal Pendidikan: Riset Dan Konseptual, 3(2), 88-98.

Verawardina, U., \& Jama, J. (2018). Philosophy TVET di era derupsi revolusi industri 4.0 di Indonesia. Jurnal Filsafat Indonesia, 1(3), 104-111.

WHO. (2020). Corona virus disease (COVID-19) pandemic. World Helath Organization. 